\title{
PERSPECTIVE
}

\section{The emerging roles of topical non-steroidal anti-inflammatory agents in ophthalmology}

\author{
Peter Koay
}

Non-steroidal anti-inflammatory drugs (NSAIDs) are a heterogeneous group of compounds which in chemical terms belong to different structural classes. By definition, NSAIDs do not include a steroid nucleus derived biosynthetically from cholesterol in their chemical structures. Although the term NSAIDs can be expanded to include other classes of compounds such as immunosuppressives and cytokine modulators, ${ }^{1}$ this discussion will be limited to commercially available topical ophthalmic drugs generally regarded as NSAIDs. Topical ophthalmic drugs under discussion are of the following chemical classes: indoles, phenylalkanoic acids, phenylacetic acids, and pyrazolons. The main topical ophthalmic drug of the indole chemical class is indomethacin. This was the first topically administered NSAID to be used widely in ophthalmic clinical studies. Phenylalkanoic acids are water soluble and are readily formulated as topical ophthalmic solutions such as flurbiprofen $0.03 \%$ (Ocufen), ketorolac tromethamine $0.5 \%$ (Acular), and suprofen $1 \%$ (Profenal). The main topical ophthalmic phenylacetic acid derivative is diclofenac $1 \%$ (Voltarol) (Table 1). NSAIDs are also known as cyclo-oxygenase inhibitors based on their mode of action, and are important mediators or modulators of ocular inflammatory reactions. ${ }^{2}$

\section{Arachidonic acid metabolites in ocular inflammation}

Activation of phospholipase $A_{2}$, following tissue insults, breaks down cell membrane phospholipids to arachidonic acid. This forms the substrate for further reactions mainly by the cyclo-oxygenase and the lipoxygenase pathways (Fig 1). Other pathways, such as the cytochrome $P_{450}$ pathway, are also involved in the production of biologically active lipids. The resulting arachidonic acid metabolites, along with other chemical mediators, interact to cause inflammation. Although arachidonic acid metabolites are associated with pro-inflammatory actions, there are a few studies to suggest that some of these metabolites also have antiinflammatory actions. ${ }^{2}$

The main products of the cyclo-oxygenase (CO) pathway are prostaglandins (PGs). In the rabbit model, PGs

Table 1 Commercially available topical ophthalmic non-steroidal anti-inflammatory drugs

\begin{tabular}{lll}
\hline Chemical class & Generic name & Trade name (Manufacturer) \\
\hline Indoles & Indomethacin & $\begin{array}{l}\text { Indomethacin 0.5\% and 1\% in } \\
\text { castor oil eyedrops (Moorfields } \\
\text { Eye Hospital) } \\
\text { Indocid ophthalmic suspension } \\
\text { (Merck, Sharp \& Dohme) }\end{array}$ \\
Phenylalkanoic acids & $\begin{array}{l}\text { Flufen (Allergan) } \\
\text { Acular (Allergan) } \\
\text { Ketorolac } \\
\text { Profenal (Alcon) } \\
\text { Poltaren/Voltarol (Ciba Vision } \\
\text { Ophthalmics) }\end{array}$ & $\begin{array}{l}\text { Ophtofenac } \\
\text { Tanderil 10\% (Geigy) }\end{array}$ \\
\hline
\end{tabular}

appear in the aqueous after ocular paracentesis, thermal or mechanical injury which cause a rise in both intraocular pressure and protein concentration in the aqueous humour. The principal source of PGs in the aqueous humour is probably derived from the iris-ciliary body. PGs cause miosis, increase in vascular permeability of the blood-ocular barriers, and changes in intraocular pressure. Furthermore, PGs are known to possess chemokinetic activity and can serve as mediators in both humoral and cellular phases of the inflammatory response. ${ }^{2}$

The main products of the lipoxygenase (LO) pathway are leukotrienes (LT) such as leukotriene $B_{4}$ and peptidoleukotrienes. Leukotriene $B_{4}$ causes aggregation of polymorphonuclear cells (PMN), PMN chemotaxis in vivo, PMN chemokinesis, exudation of plasma, translocation of calcium, and stimulation of phopholipase $A_{2}$. Peptidoleukotrienes result in bronchoconstriction, secretion of mucus, plasma leakage from post capillary venules, vasoconstriction of arterioles, and miosis. ${ }^{2}$

Inflammation is complex involving a large number of mediators and products. NSAIDs inhibit the cyclooxygenase enzyme (Fig 1) but not the lipoxygenase enzyme. Thus, NSAIDs inhibit the biosynthesis of PGs but not LTs. Inhibition of PG biosynthesis inhibits intraoperative miosis during cataract surgery, reduces the vascular permeability of the blood-ocular barrier, and modifies inflammation. It should be noted, however, that NSAIDs are not capable of inhibiting the actions of PGs once formed. ${ }^{3}$

Glucocorticoids inhibit the phospholipase $A_{2}$ enzyme (Fig 1), thus inhibiting the biosynthesis of arachidonic acid itself. This results in the inhibition of the biosynthesis of both PGs and LTs. Other effects of glucocorticoids not directly involved in the arachidonic pathway include: effects on white cells (inhibit migration of macrophages, neutropenia, lymphocytopenia, eosinopenia, monocytopenia, neutrophilic leucocytosis); inhibition of degranulation of neutrophils, mast cells, basophils; lysosome stabilisation; suppression of lymphokines; reduction of capillary permeability; and suppression of vasodilatation. ${ }^{4}$

\section{Ocular penetration and distribution of topical ophthalmic NSAIDs}

Indomethacin is soluble in alcohol but not in water and was initially formulated for ophthalmic clinical studies using a sesame oil vehicle which proved to be irritating. An aqueous suspension of indomethacin $1 \%$ is now available and shaking the bottle is recommended. ${ }^{5}$ Indomethacin has been shown to significantly decrease levels of prostaglandin $\mathrm{E}_{2}$ in the human cornea. ${ }^{6}$ In an animal model, topical $1 \%$ indomethacin suspension resulted in high concentrations in the cornea, but low concentrations in the iris, the ciliary body, the lens, and the choroid. ${ }^{7}$ 


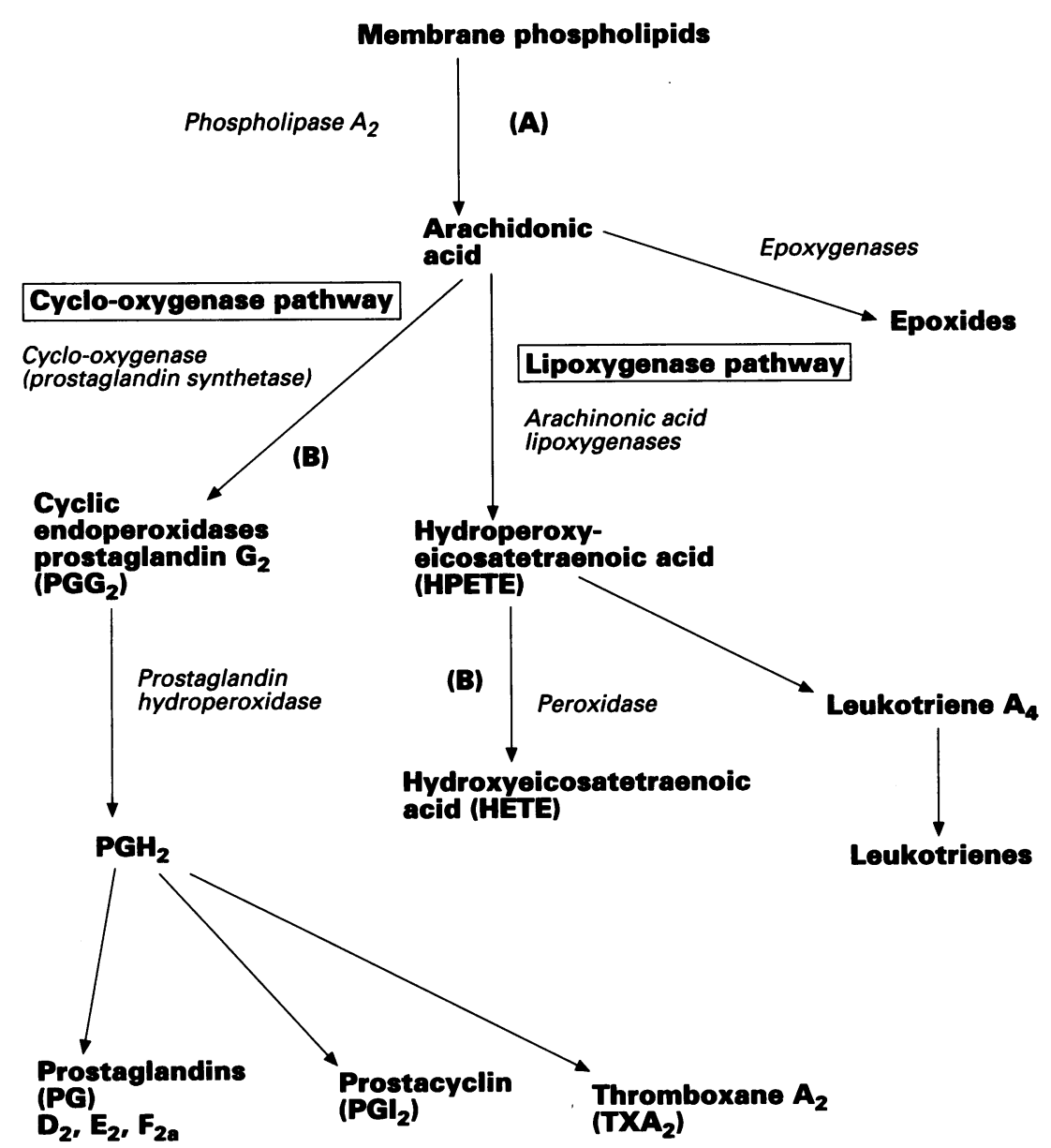

Figure 1 A simplified schematic representation of the enzymatic pathways of arachidonic acid metabolism. Site of action of glucocorticoids (A) and NSAIDs (B).

Topical administration of indomethacin appears to produce better penetration into the eye than oral administration. ${ }^{8}$

Commercially available topical NSAIDs generally have good ocular penetration. Topical use of flurbiprofen or ketorolac will result in the distribution of the drug throughout the conjunctiva, cornea, aqueous, sclera, iris, ciliary body, and choroid-retina in rabbits. ${ }^{910}$ Diclofenac applied topically readily penetrates the cornea and into the aqueous. ${ }^{11}$ Systemic absorption of topical NSAIDs is minimal as demonstrated by the plasma levels of diclofenac following ocular instillation (two drops of diclofenac to each eye) being below the limit of quantification $(10 \mathrm{ng} / \mathrm{ml})$ over a 4 hour period. ${ }^{12}$

\section{Potential advantages of topical NSAIDs over corticosteroids}

The main advantage of topical NSAIDs is that the undesirable effects of topical corticosteroids are avoided. These include decreased immunological response to infection, ${ }^{13}$ cataract formation, ${ }^{14}$ and steroid-induced raised intraocular pressure (IOP) ${ }^{15} \mathrm{~A}$ study of steroid responsive patients revealed that flurbiprofen has no effect upon the elevation of IOP compared with dexamethasone. ${ }^{16}$ Topical diclofenac $0 \cdot 1 \%$ had no significant effect on IOP following cataract surgery compared with placebo. ${ }^{17}$ Furthermore, the use of NSAIDs such as flurbiprofen sodium or diclofenac sodium does not exacerbate acute herpetic keratitis or prolong viral shedding. ${ }^{18}$

In animal models, low therapeutic doses of cortisone have been noted to have no significant effect on epithelial regeneration. However, large doses of cortisone retard epithelial and endothelial regeneration. Large doses also retard the formation of fibrinous coagulum, cellular infiltration, and fibroblastic repair. ${ }^{19}$ Srinivasan, in a series of experiments involving mechanical corneal injury, demonstrated in a rabbit model that corticosteroids (prednisolone acetate $1 \%$, dexamethasone $0 \cdot 1 \%$, and fluorometholone $1 \%$ ) appear to inhibit re-epithelialisation by mainly conjunctival epithelial cells following complete epithelial denudation. These corticosteroids do not inhibit reepithelialisation by mainly corneal epithelial cells after partial epithelial denudation. NSAIDs (indomethacin $0.5 \%$ and flurbiprofen $0.01 \%$ ) in contrast, do not inhibit the re-epithelialisation by either corneal or conjunctival epithelial cells. ${ }^{20}$ Topical diclofenac sodium $0 \cdot 1 \%$ does not delay re-epithelialisation following excimer laser treatment in rabbit corneas. ${ }^{21}$ However, Hersh et al in their study of epithelial scrape wound healing in rabbits demonstrated a delay in epithelial healing for the first 3 days when NSAIDs (flurbiprofen sodium $0.03 \%$, diclofenac sodium $0.1 \%$ ) or steroids (prednisolone acetate $1 \%$ ) were used compared with placebo vehicle. ${ }^{22}$

Corticosteroids can result in decreased stromal corneal wound healing. ${ }^{23}$ One rabbit study involving full thickness corneal wounds demonstrated that treatment with flurbiprofen sodium or diclofenac sodium actually resulted in stronger scars than untreated controls. Corneal wounds treated with prednisolone acetate resulted in the weakest scar. ${ }^{24}$ In another rabbit study, the effects of equipotent anti-inflammatory doses of flurbiprofen and prednisolone on the wound bursting pressure of $4 \mathrm{~mm}$ corneal incisions were compared. The results of this study suggest that flurbiprofen and prednisolone do not differ in their effects on corneal wound healing. ${ }^{25}$ Topical flurbiprofen $0.03 \%$ and prednisolone acetate $1 \%$ show similar astigmatic decay 
curves following $6.5 \mathrm{~mm}$ scleral pocket cataract surgery with no clinical or statistical difference in the astigmatic results 4 months after surgery. ${ }^{26}$ Although the advantage of NSAIDs over corticosteroids regarding corneal epithelial healing and wound strength is far from certain, the findings might favour the use of topical NSAIDs.

\section{Use of topical NSAIDs in reducing postoperative inflammation}

Postoperative inflammation may be evaluated by clinical biomicroscopy examination and by anterior fluorophotometry. The latter assumes a correlation between inflammation and breakdown of the blood-aqueous barrier as measured by accumulation of fluorescein in the anterior chamber. Fluorophotometry allows for quantification, better reproducibility, and greater objectivity in the evaluation of postoperative inflammation.

Topical ketorolac tromethamine $0.5 \%$ is effective in reducing clinical and anterior fluorophotometric postoperative inflammation when compared with placebo 2728 and dexamethasone $0.1 \% \%^{29}$ in extracapsular cataract extraction. Topical diclofenac sodium $0 \cdot 1 \%$ was favoured over placebo at 4,8 , and 15 days after cataract surgery for clinical assessments of anterior chamber cells, flare, conjunctival erythema, and ciliary flush. ${ }^{31}$ Kraff et $a l^{32}$ in a study without concomitant steroidal anti-inflammatory agents, showed significantly better 'summed flare and anterior chamber cells score' at 2 to 5 days and 7 to 9 days after cataract surgery in patients receiving diclofenac sodium $0.1 \%$ than in those on placebos. Brennan et $a^{33}$ found no difference in postoperative inflammation (evaluated by slitlamp assessment of cell and flare, and objectively by using the Kowa FC-1000 laser cell and flare meter) between diclofenac sodium $0 \cdot 1 \%$ (Voltaren) and prednisolone acetate $1 \%$ (Pred forte) in patients undergoing phacoemulsification and posterior chamber intraocular lens implant. Furthermore, topical diclofenac sodium $0 \cdot 1 \%$ has been shown to be superior to prednisolone sodium phosphate $1 \%$ in reducing anterior fluorophotometric postoperative inflammation. ${ }^{34}$ The effects of NSAIDs in postoperative inflammation following laser trabeculoplasty ${ }^{35-37}$ and cyclocryotherapy ${ }^{38}$ are under investigation.

\section{Effectiveness of topical NSAIDs on symptoms of allergic conjunctivitis}

Seasonal allergic conjunctivitis is characterised by itching, burning, tearing, and lid oedema in response to exposure to airborne allergens. Although histamine release is recognised as a cause of itching, other mediators such as prostaglandins, leukotrienes, and platelet activating factors are involved. NSAIDs act by interrupting the synthesis of prostaglandins which may lower the threshold of histamine induced itching and influence the nerve responsiveness to itching. In a double masked randomised trial in patients with seasonal allergic conjunctivitis, although placebo treated eyes experienced some relief due to the dilution of antigens, ketorolac tromethamine $0.5 \%$ has been shown to significantly reduce the severity of the associated ocular itching. ${ }^{39}$ A study comparing the effects of diclofenac sodium $0.1 \%$ and ketorolac tromethamine $0.5 \%$ showed similar efficacy in treating ocular itching and bulbar injection. ${ }^{40}$ Diclofenac $0 \cdot 1 \%$ is effective in the treatment of episcleritis, hay fever conjunctivitis, phlyctenular conjunctivitis, and corneal limbal ulcers, replacing or in conjunction with corticosteroids. ${ }^{41}$ Oxyphenbutazone (Tanderil eye ointment) ${ }^{42}$ has been shown to be ineffective for allergic conjunctivitis and has the added problem of some patients being intolerant of the ointment base. ${ }^{43} 44$
Inhibition of intraoperative miosis with topical NSAIDs

The use of preoperative topical parasympatholytic and sympathomimetic agents with intraoperative sympathomimetics ${ }^{45}$ is effective in keeping the pupil dilated during cataract surgery. Topical flurbiprofen $0.03 \%$, suprofen $1 \%$, diclofenac sodium $0.1 \%$, and indomethacin $1 \%$ appear to have a small statistical effect on inhibiting intraoperative miosis. ${ }^{46-48}$ This may or may not be clinically significant depending on surgical technique and viscoelastic technique in use.

\section{Prevention and treatment of pseudophakic or aphakic cystoid macular oedema with topical NSAIDs}

Although the exact aetiology of cystoid macular oedema (CMO) has not been established, ocular inflammation involving prostaglandins has been implicated. 4950 Prostaglandins cause increased capillary leakage, breakdown of the blood-aqueous barrier, and perifoveal capillary dilatation. Other possible factors affecting the incidence of CMO include the type of surgery (for example, phacoemulsification, intracapsular or extracapsular cataract surgery), primary capsulotomy, phototoxicity, and the role of other autocoids (for example, bradykinin, serotonin). ${ }^{51}$ The natural history of spontaneous resolution in CMO complicates the interpretation of the efficacy of modifying agents. In the study of CMO, it is useful to distinguish angiographic CMO from clinically significant CMO that includes a reduction of the measurable variables of vision. Angiographic evidence of CMO occurs in as many as $50-70 \%$ of postoperative cataract patients with only approximately $1 \%$ of patients suffering significant loss of vision. ${ }^{52}$

Prophylactic use of topical indomethacin $1 \%$ with concurrent corticosteroids is effective in reducing angiographic CMO in the short term (within 7 months) but did not, in early studies (with one exception ${ }^{53}$ ), demonstrate a beneficial effect on visual acuity. ${ }^{54} 55$ The use of topical diclofenac five times daily until discharge and subsequently three times daily for 6 months with concurrent corticosteroids has been shown to significantly reduce the incidence of angiographic CMO in intracapsular cataract surgery. ${ }^{56}$ Treatment with topical ketorolac tromethamine $0.5 \%$ without concurrent steroids before and after cataract surgery is effective in reducing postoperative angiographic CMO but produces no significant difference in the visual acuity results. ${ }^{57}$

One recent study demonstrated that flurbiprofen $0.03 \%$ and indomethacin $1 \%$ (with concurrent corticosteroids in approximately $88 \%$ of the patients in each group) reduces the incidence of both angiographic CMO and clinical CMO (defined as reduced Snellen visual acuity and contrast sensitivity) from day 21 to day 60 after extracapsular cataract surgery. These topical NSAIDs were used four times daily 2 days before surgery, half hourly for 2 hours before surgery, and four times daily after surgery for 3 months. ${ }^{58}$ The use of flurbiprofen $0.03 \%$ appears to significantly improve contrast sensitivity with or without CMO at 12 cycles per degree. In the presence of CMO, patients using flurbiprofen generally had higher contrast sensitivity scores than patients using the placebo vehicle. ${ }^{59}$

Flach et $a^{60}$ showed that there was improvement in distance visual acuity in patients with angiographically proved chronic CMO (visual acuity less than or equal to $20 / 40$ for 6 months) treated with ketorolac tromethamine $0.5 \%$ when compared with placebo. In a study involving 30 eyes with chronic CMO after cataract surgery, Peterson et al 
were able to demonstrate $80 \%$ improvement of three lines or more when using topical indomethacin $1 \%{ }^{61}$ Furthermore, $53 \%$ of these patients demonstrated an 'on/off' phenomenon induced by the initiation and cessation of treatment documented by visual acuity measurements and fluorescein angiography. Treatment of confirmed symptomatic CMO with fenoprofen $1 \%$ resulted in visual improvement that was not statistically significant. ${ }^{62}$

In conclusion, topical NSAIDs help to maintain the blood-aqueous barrier after ocular surgery. Although the number of cases of clinically significant CMO may be small, the consequences for the patient can be profound. ${ }^{63}$ Topical NSAIDs may reduce this risk and improve the visual outcome.

\section{Analgesic effects of topical NSAIDs}

Following excimer photorefractive keratectomy (PRK) patients may experience significant ocular pain and discomfort until corneal re-epithelialisation. Hyperaesthesia may occur following excimer laser ablation. ${ }^{64}$ Studies on topical diclofenac sodium show that it reduces corneal sensitivity, ${ }^{65}$ has an anaesthetic effect, ${ }^{66}$ and decreases discomfort after excimer laser treatment. ${ }^{67}$ Sher et al ${ }^{68}$ have reported, in a clinical series of 16 diclofenac treated patients and 16 placebo patients, that topical diclofenac appears to significantly reduce the ocular pain following excimer PRK. Diclofenac treated patients rarely experience the early post-PRK peak in pain and have less pain overall. In addition, such patients have significantly less post-laser photophobia, burning, and stinging symptoms. Significantly fewer patients prescribed topical diclofenac require oral narcotics. Topical ketorolac tromethamine $0.5 \%$ (Acular) has also been reported as an analgesic. ${ }^{69-71}$ There is no statistical difference in the effectiveness of topical ketorolac compared with topical diclofenac on discomfort following radial keratotomy. ${ }^{72}$ Painful ocular conditions such as episcleritis and corneal limbal ulcers may benefit not only from the corticosteroid sparing effect of diclofenac sodium $0 \cdot 1 \%$ but also from its analgesic properties. ${ }^{30}$ Indomethacin does not appear to have any significant analgesic activity. ${ }^{73}$

\section{Effects of topical NSAIDs following excimer laser treatment}

The cornea has a lesser capacity to synthesise cyclo-oxygenase and lipoxygenase products from arachidonic acid than the conjunctiva and anterior uvea. ${ }^{74}$ Nevertheless, following the application of $193 \mathrm{~nm}$ excimer laser on rabbit corneas, prostaglandin $\mathrm{E}_{2}\left(\mathrm{PGE}_{2}\right)$ production (mediated by the cyclo-oxygenase pathway) has been noted to be rapid and sustained with leucocyte infiltration in the cornea without significant change in the levels of leukotriene $\mathrm{B}_{4}$ (mediated by the lipoxygenase pathway). ${ }^{75}$ In another experiment, $193 \mathrm{~nm}$ excimer laser irradiation caused a greater increase in $\mathrm{PGE}_{2}$ production in rabbit corneal tissue (8.6-fold increase in $\mathrm{PGE}_{2}$ compared with unoperated cornea) than keratectomy with a microkeratome to the same depth. ${ }^{76}$ These observations suggest that the inflammatory responses following excimer laser irradiation are mediated primarily by prostaglandins.

In mammalian cell cultures, ultraviolet A light stimulates cyclo-oxygenase metabolism and produces high levels of $\mathrm{PGE}_{2}{ }^{77}$ which acts as a chemoattractant for polymorphonuclear leucocytes (PMNs). ${ }^{78}$ Topical diclofenac sodium $0 \cdot 1 \%$ was shown to reduce the local release of $\mathrm{PGE}_{2}$ and the migration of PMNs in the rabbit cornea after $193 \mathrm{~nm}$ excimer laser ablation. ${ }^{79}$ Diclofenac was also shown to inhibit the chemokinetic activity (speed of PMN migration) of human PMNs elicited in vitro. ${ }^{80}$ In another study, postoperative topical diclofenac sodium treatment resulted in a significant decrease in prostaglandin $\mathrm{E}_{2}$ levels and a significant increase in corneal leucocytes at 10 hours. Treatment with fluorometholone, a corticosteroid, did not significantly alter prostaglandin $\mathrm{E}_{2}$ levels but depressed leucocyte ingress. ${ }^{58} \mathrm{PMNs}$ in tear fluid of rabbits subjected to corneal de-epithelialisation are inhibited by topically applied flurbiprofen $0.01 \%$, indomethacin $0.5 \%$, and aspirin $0.5 \%$. ${ }^{81}$

PMNs play a central role in the inflammatory process. In a study involving experimental keratitis, the ability of a NSAID (suprofen) and a corticosteroid (prednisolone acetate) to suppress PMN invasion of the rabbit cornea was evaluated. Suprofen therapy initiated immediately after induction of inflammation was ineffective and was only efficacious if therapy was actually started 48 hours before corneal injury. In contrast, prednisolone acetate therapy was effective when initiated immediately after induction of inflammation. Prednisolone acetate therapy, in addition, produced a marked increase in therapeutic effect when started 48 hours before the insult. Combined treatment of suprofen and prednisolone acetate was significantly more effective than with either drug alone. ${ }^{82}$ In a small clinical trial, concurrent use of corticosteroids and NSAIDs appeared to reduce myopic regression for 1 year after PRK and the effect was more pronounced with flurbiprofen sodium than diclofenac sodium. ${ }^{83}$

The use of NSAIDs without corticosteroids following excimer PRK has resulted in cases of corneal infiltrates. Theoretical inhibition of the cyclo-oxygenase pathway for prostaglandin generation may result in increased formation of leukotrienes recognised as chemotactic for $\mathrm{PMNs}^{84-86}$ and this may encourage PMN infiltrate formation in the earlier healing stage. It has been suggested that patients taking NSAIDs alone may experience more corneal haze and regression of effect. ${ }^{87}$ However, in a study comparing the use of a topical NSAID (diclofenac sodium $0 \cdot 1 \%$ ) and corticosteroids (dexamethasone $0 \cdot 1 \%$ ) 20 consecutive eyes of 10 patients ( 4 to 9 dioptres myopia intended correction) showed no statistical difference in haze or regression effect. ${ }^{88}$ Experimental work on rabbits treated with $193 \mathrm{~nm}$ excimer laser myopic PRK to correct 5 dioptres, showed less corneal haze in the group receiving post-laser topical diclofenac $0 \cdot 1 \%$ and fluorometholone $0 \cdot 1 \%{ }^{89}$ The usefulness of specific NSAIDs in excimer PRK with regard to corneal haze and regression is still uncertain.

\section{Adverse reactions, precautions, and interactions of topical NSAIDs}

Frequently reported adverse reactions of NSAIDs include transient burning, stinging, and minor signs of ocular irritation on instillation. Hypersensitivity reactions with itching, reddening, photosensitivity, and keratitis punctata may occur. These reactions may be seen especially in patients with asthma, ${ }^{90}$ urticaria, or acute rhinitis and patients who have symptoms precipitated by drugs with prostaglandin synthetase inhibiting activity (for example, acetylsalicylic acid). ${ }^{91} 92$ There have been reports that topical flurbiprofen may cause an increase in bleeding tendency of ocular tissues in conjunction with surgery. ${ }^{88}$ Although there have been no reported adverse events, there is a theoretical possibility that patients receiving other medications which prolong bleeding time, or with known haemostatic defects, may experience exacerbation of bleeding with topical flurbiprofen and diclofenac. ${ }^{87} 88$ It is advisable that patients with a history 
of herpes simplex keratitis using NSAIDs should be monitored. As there are no adequate studies in pregnant women, topical NSAIDs should be avoided in these patients.

Prostaglandins such as the topical $\mathrm{PGF}_{2 \alpha}$ isopropylester series can cause reductions of intraocular pressure by enhancing uveoscleral outflow in laboratory and clinical trials. ${ }^{93-96}$ NSAIDs which block prostaglandin synthesis may thus possibly interfere with the hypotensive effects of prostaglandins. In a rabbit model, topical flurbiprofen $0.03 \%$ can interfere with the ocular hypotensive efficacy of topical epinephrine (adrenaline) $1 \%$ but not with the hypotensive efficacy of topical carbonic anhydrase inhibitors. ${ }^{9798}$ Further clinical studies are required.

\section{The future of topical NSAIDs}

In cataract surgery, a single topical agent with multiple effects is potentially attractive for routine use. NSAIDs can inhibit intraoperative miosis and prostaglandin release, act as a postoperative anti-inflammatory agent with analgesic properties, and reduce the risk of cystoid macula oedema. However, the widespread use of NSAIDs is currently hindered by their relatively high cost, especially with unit dose packaging and prolonged treatment regimens. This situation will hopefully improve as more NSAIDs become commercially available.

\section{Darlington Memorial Hospital,}

P KOAY

\section{Darlington DL3 6HX}

1 Rosenbaum JT. Towards cytokine insight in sight. Br f Ophthalmol 1995; 79: $970-1$

2 Bhattacherjee $P$. The role of arachidonate metabolites in ocular inflammation The ocular effects of prostaglandins and other eicosanoids. New York: Alan R Liss, 1989: 211-27.

3 Van Husen $H$. Topical treatment of anterior ocular diseases with diclofenac Na eye drops. Klin Monatsbl Augenheilkd 1986; 188: 615-9.

4 Flach AJ. Cyclo-oxygenase inhibitors in ophthalmology. Surv Ophthalmo 1992; 36: 259-84.

5 Srobel J. Concentration of locally applied indomethacin eye drops for the inhibition of prostaglandin synthesis in the eye. Ophthalmology 1991; 202: 43-7.

6 Frucht-Pery J, Zauberman $\mathrm{H}$. The effect of indomethacin on prostaglandin E2 in human cornea and conjunctiva. Arch Ophthalmol 1992; 110: 343-5.

7 Spiess BM, Mathis GA, Franson KL, Leber A. Kinetics of uptake and effects of topical indomethacin application on protein concentration in the aqueous humor of dogs. Am $\mathcal{F}$ Vet Res 1991; 52: 1159-63.

8 Sanders DR, Kraff MC, Goldstick B. Aqueous penetration of oral and topical indomethacin in humans. Arch Ophthalmol 1983; 101: 1614-6.

9 Anderson JA, Chen CC, Vita JB. Disposition of topical flurbiprofen in normal and aphakic rabbit eyes. Arch Ophthalmol 1982; 100: 642-5.

10 Ling TL, Comb DL. Ocular bioavailability and tissue distribution of ketorolac tromethamine in rabbits. F Pharm Sci 1987; 76: 289-94.

11 Goa KL, Chrisp P. Ocular diclofenac: a review of its pharmacology and clinical use in cataract surgery and potential in other inflammatory ocular conditions. Drugs Aging 1992; 2: 478-9.

12 Voltaren $11 / 93$, CS665633.

13 Fraser-Smith EB, Matthews TR. Effect of ketorolac on Pseudomonas aeruginosa ocular infection in rabbits. $f$ Ocular Pharmacol 1988; 4: 101-9.

14 Kana JS, Wiederholt M. Corticosteroid and the active ion transport of the isolated human lens. Ann Ophthalmol 1984; 16: 1034-9.

15 Hic J, Gigon S, Leuenberger PM. Comparison of the anti-inflammatory effect of dexamethasone and diclofenac ophthalmic preparations. Klin Monatsbl Augenheilkd 1984; 184: 494-8.

16 Geiser DK, Hodapp E, Goldberg I, Kass MA, Becker B. Flurbiprofen and intraocular pressure. Ann Ophthalmol 1981; 13: 831-3.

17 Strelow SA, Sherwood MB, Broncato LJB, Napier A, Driebe WT, Guy JR et al. The effect of diclofenac sodium ophthalmic solution on intraocula pressure following cataract extraction. Ophthalmic Surg 1992; 23: 170-5.

18 Trousdale MD, Barlow WE, McGuigan LJB. Assessment of diclofenac on herpes keratitis in rabbit eyes. Arch Ophthalmol 1989; 107: 1664-6.

19 Ashton N, Cook C. Effect of cortisone on healing of corneal wounds. $\mathrm{Br} \mathfrak{F}$ Ophthalmol 1951; 35: 708 .

20 Srinivasan BD. Corneal reepithelialization and anti-inflammatory agents [Review]. Trans Am Ophthalmol Soc 1982; 80: 758-822.

21 Loya N, Bassage S, Vyas S, del Cerro M, Park SB, Aquavella JV. Topical diclofenac following excimer laser: effect on corneal sensitivity and wound healing in rabbits. $\mathcal{F}$ Refract Corneal Surg 1994; 10: 423-7.

22 Hersh PS, Rice BA, Baer JC, Wells PA. Topical nonsteroidal agents and corneal wound healing. Arch Ophthalmol 1990; 108: 577-83.

23 Henahan JF. Wounds destabilised by steroids more than by incision sutures. Ophthalmology Times 1992; 8.

Ophthalmology Times 1992; 8 .
24 McCarey BE, Napalkov JA, Pippen PA, Reaves TA. Corneal wound healing strength with topical anti-inflammatory drugs. Invest Ophthalmol Vis $S c$ 1993; 34: 1321 .

25 Miller D, Gruenberg P, Miller R, Bergamini MVW. Topical flurbiprofen or prednisolone: effect on corneal wound healing in rabbits. Arch Ophthalmo 1981; 99: 681-2.
26 Masket S. Comparison of the effect of topical corticosteroid and nonsteroidals on postoperative corneal astigmatism. $\mathcal{f}$ Cataract Refract Surg $1990 ; 16: 715-8$

27 Flach AJ, Lavelle CJ, Olander KW, Retzlaff JA, Sorenson LW. The effect of ketorolac tromethamine solution $0.5 \%$ in reducing postsurgical inflammation after cataract extraction and intraocular lens implantation. Ophthalmology 1988; 95: 1279-84.

28 Flach AJ, Graham J, Kruger L, Stegman RC, Tanenbaum L. Quantitative assessment of postsurgical breakdown of the blood aqueous barrier following administration of ketorolac tromethamine solution: a doublemasked, paired comparison with vehicle-placebo solution study. Arch Ophthalmol 1988; 106: 344-7.

29 Flach AJ, Jaffe NS, Akers WA. The effect of ketorolac tromethamine in reducing postoperative inflammation: a double-masked parallel comparison with dexamethasone. Ann Ophthalmol 1989; 21: 407-11.

30 Flach AJ, Kraff MC, Sanders DR, Tanenbaum L. The quantitative effect of $0.5 \%$ ketorolac tromethamine solution and dexamethasone sodium phosphate solution on the post-surgical blood-aqueous barrier. Arch Ophthalmol 1988; 106: 480-3.

31 Vickers FF, McGuigan LJB, Ford C, Wysowskyj H, Mellars K, Koester J, et al. The effect of diclofenac sodium ophthalmic on the treatment of postoperative inflammation. Invest Ophthalmol Vis Sci 1991; 32: 793

32 Kraff MC, Martin RG, Nuemann AC, Weinstein AJ. Efficacy of diclofenac sodium ophthalmic solution versus placebo in reducing inflammation following cataract extraction and posterior chamber lens implantation. $f$ Cataract Refract Surg 1994; 20: 138-44.

33 Brennan KM, Brown RM, Roberts CW. A comparison of topical nonsteroidal anti-inflammatory drugs to steroids for control of post cataract inflammation. Insight 1993; 18: 8-9, 11.

34 Kraff MC, Sanders DR, MCGuigan L, Raanan MG. Inhibition of bloodaqueous humor barrier breakdown with diclofenac. A fluorophotometric study. Arch Ophthalmol 1990; 108: 380-3.

35 Hotchkiss ML, Robin AL, Pollack IP, Quigley HA. Nonsteroidal antiinflammatory agent after argon laser trabeculoplasty. A trial with flurbiprofen and indomethacin. Ophthalmology 1984; 91: 969-76.

36 Weinreb RN, Robin AL, Baerveldt G, Drake MV, Blumenthal M, Wilensky J. Flurbiprofen pre-treatment in argon laser trabeculoplasty for primary open-angle glaucoma. Arch Ophthalmol 1984; 102: 1629-32.

37 Goethals M, Missotten L. Efficacy and safety of indomethacin $0 \cdot 1 \%$ versus flurbiprofen $0.03 \%$ eye drops in inflammation after argon laser trabeculoplasty. Doc Ophthalmol 1994; 85: 287-93.

38 Hurvitz LM, Spaeth GL, Zakhour I, Mahmood E, Murray G. A comparison of the effect of flurbiprofen, dexamethasone and placebo on cyclocryotherapy-induced inflammation. Ophthalmic Surg 1984; 15: 394-9.

39 Garry R. Ketorolac tromethamine: a non-steroidal anti-inflammatory agent for ophthalmic use in the management of ocular itching associated with seasonal allergic conjunctivitis. Allergan Technical Report 1993.

40 Tauber J, Abelson M, Ostrov C, Laibovitz R, Raizman M, Betts J, et al. A multicenter comparison of diclofenac sodium $0.1 \%$ to ketorolac tromethamine $0.5 \%$ in patients with acute seasonal allergic conjunctivitis. Invest Ophthalmol Vis Sci 1994; 35 (suppl): 1291.

41 Van Husen $H$. Topical treatment of anterior ocular diseases with diclofenac Na eye drops. Klin Monatsbl Augenheilkd 1986; 188: 615-9.

42 Murphy JE. Drug profile: Tanderil eye ointment. F Int Med Res 1973; 1: $136-40$.

43 Rushford WAI, Holman RM, Pulvertaft TB. Tanderil/Chloramphenicol eye ointment in the treatment of the 'Red eye' seen in general practice. F Int Med Res 1978; 6: 141-3.

44 Emery DG, Smith VH, Wilkinson P. A trial of oxyphenbutazone eye ointment in general practice. Practitioner 1973; Dec: 3-7.

45 Gimbel HV. The effect of treatment with topical nonsteroidal anti-inflammatory drugs with and without intra-operative epinephrine on the maintenance of pupillary mydriasis during cataract surgery. Ophthalmology 1989; 96: 585-8.

46 Bonomi L, Totolo G, Marchini G, Rigotti P, Ghini M. Prevention of trauma induced miosis during cataract extraction by diclofenac sodium. New Trends in Ophthalmology 1987; 2: 512-8.

47 Goa KL, Chrisp P. Ocular diclofenac: a review of its pharmacology and clinical use in cataract surgery and potential in other inflammatory ocular clinical use in cataract surgery and po

48 Psilas K, Kalogeropoulos C, Loucatzicos E, Asproudis I, Petroutsos G. The effect of indomethacin, diclofenac and flurbiprofen on the maintenance of mydriasis during extracapsular cataract extraction. Doc Ophthalmol 1992; 81: 293-300.

49 Norton AL, Brown WJ, Carson M. Pathogenesis of aphakic macular edema. Am $\mathcal{F}$ Ophthalmol 1975; 80: 86-101.

50 Obstbaum SA, Galin MA. Cystoid macular edema and ocular inflammation. The corneo-retinal inflammatory syndrome. Trans Ophthalmol Soc UK 1979; 99: 187-91.

51 Kraff MC, Sanders DR, Jampol LM, Lieberman HL. Factors affecting pseudophakic cystoid macular edema: five randomised trials. $\mathcal{F}$ Am Intraocul Implant Soc 1985; 11: 380-5.

52 Abelson MB, Parver L. How to handle CME in pseudophakes. Rev Ophthalmol 1994; Oct: 138-9.

53 Miyake K, Sakamura S, Muira H. Long-term follow-up study on the prevention of aphakic cystoid macular edema by topical indomethacine. $\mathrm{Br} F$ Ophthalmol 1980; 64: 324-8.

54 Yannuzzi LA, Landau AN, Turtz AL. Incidence of aphakic cystoid macular edema with the use of topical indomethacine. Ophthalmology 1981; 88: 947-54.

55 Kraff MC, Sanders DR, Jampol LM, Peyman GA, Lieberman HL. Prophylaxis of pseudophak cystoid macular edema with topical indomethacin. Ophthalmology 1982; 89: 885-90.

56 Quentin CD, Behrens-Baumann W, Gaus W. Prophylactic treatment of cystoid macula oedema with diclofenac eye drops in intracapsular cataract extraction with the Choyce Mark IX anterior chamber lens. Fortschr Ophthalmol 1989; 86: 546-9.

57 Flach AJ, Stegman RC, Graham J, Kruger LP. Prophylaxis of aphakic cystoid macular edema without corticosteroids. Ophthalmology 1990; 97: 1253-8.

58 Solomon LD. Efficacy of topical flurbiprofen and indomethacin in preventing pseudophakic cystoid macular edema. $\mathcal{F}$ Cataract Refract Surg 1995; 21: 73-81.

59 Ginsburg AP, Cheetham JK, DeGryse RE, Abelson M. Effects of flurbiprofen and indomethacin on acute cystoid macular edema after cataract 
surgery: functional vision and contrast sensitivity. $\mathcal{F}$ Cataract Refract Surg 1995; 21: 82-92.

60 Flach AJ, Dolan BJ, Irvine AR. Effectiveness of ketorolac tromethamine $0.5 \%$ ophthalmic solution for chronic aphakic and pseudophakic cystoid macular oedema. Am $\mathcal{F}$ Ophthalmol 1987; 103: 479-86.

61 Peterson M, Yoshizumi MO, Hepler R, Mondino B, Krieger A. Topical indomethacin in the treatment of chronic cystoid macular edema. Graefes Arch Clin Exp Ophthalmol 1992; 230: 401-5.

62 Burnett J, Tessler H, Isenberg S, Tso MO. Double-masked trial of fenoprofen sodium: treatment of chronic aphakic cystoid macular edema. Ophthalmic Surg 1983; 14: 150-2.

63 Drolsum L, Haaskjold E. Causes of decreased visual acuity after cataract extraction. $\mathcal{f}$ Cataract Refract Surg 1995; 21: 59-63.

64 Ishikawa $T$, del Cerro $M$, Liang $F Q$ Kim JC, Aquavella JV Hypersensitivity following excimer laser ablation through the corneal epithelium. Refract Corneal Surg 1992; 8: 466-74.

65 Szerenyi K, Sorken K, Garbus JJ, Lee M, Mc Donnell PJ. Decrease in normal human corneal sensitivity with topical diclofenac sodium. $A m \mathcal{f}$ Ophthalmol 1994; 118: 312-5.

66 Kaidman GW. Diclofenac and its effect on corneal sensation. Arch Ophthalmol 1995; 113: 262.

67 Harr D. PRK: no pain, major gain. Ocular Surg News 1992; 21: 73-4.

68 Sher NA, Frantz JM, Talley A, Parker P, Lane SS, Ostrov C, et al. Topical diclofenac in the treatment of ocular pain after excimer photorefractive keratectomy. Refract Corneal Surg 1993; 9: 425-36.

69 Ekdahl J. Promising use of non-steroidals with PRK. Eyecare Technology 1994; 4: 58-105.

70 Stein R, Stein HA, Cheskes A, Symons S. Photorefractive keratectomy and post-operative pain. Am $\mathcal{F}$ Ophthalmol 1994; 117: 403-5.

71 Donnenfeld ED, Selkin BA, Perry HD, Moadel K, Selkin GT, Cohen AJ, et al. Controlled evaluation a bandage contact lens and a topical nonsteroidal anti-inflammatory drug in treating traumatic corneal abrasions. Ophthalmology 1995; 102: 979-84.

72 Epstein RL, Laurence EP. Relative effectiveness of topical ketorolac and topical diclofenac on discomfort after radial keratotomy. $\mathcal{F}$ Cataract Refract Surg 1995; 21: 156-9.

$73 \mathrm{Hoh} \mathrm{H}$. Local anaesthetic effect and subjective tolerance of $0.5 \%$ levobunolol in normal eyes. Klin Monatsbl Augenheilkd 1990; 1: 20-6.

74 Kulkarni PS, Srinivasan BD. Cyclooxygenase and lipoxygenase pathways in anterior uvea and conjunctiva [Review]. Progr Clin Biol Res 1989; 312: 39-52.

75 Phillips AF, Szerenyi K, Campos M, Krueger RR, McDonnell PJ Arachidonic acid metabolites after excimer laser corneal surgery. Arch Ophthalmol 1993; 111: 1273-8.

76 Szerenyi KD, Campos M, McDonnell PJ. Prostaglandin E2 production after lamellar keratectomy and photorefractive keratectomy. $\mathcal{F}$ Refract Corneal Surg 1994; 10: 413-6.

77 Hanson DL, DeLeo VA. Long wave ultraviolet radiation stimulates arachidonic acid release and cyclooxygenase activity in mammalian cell culture. donic acid release and cyclooxygenase
Photochem Photobiol 1989; 49: 423-30.

78 Levine JD, Gooding J, Donatoni P, Borden L, Goetzl EJ. The role of the polymorphonuclear leukocyte in hyperalgesia. $f$ Neurosci 1985; 5: 3025-9.
79 Szerenyi K, Wang XW, Lee M, Mc Donnell PJ. Topical diclofenac treatment prior to excimer laser photorefractive keratectomy in rabbits. Refract Corneal Surg 1993; 9: 437-42.

80 Perianin A, Gougerot-Pocidalo MA, Giroud JP, Hakim J. Diclofenac sodium, a negative chemokinetic factor for neutrophil locomotion. Biochem Pharmacol 1985; 34: 3433-8.

81 Srinivasan BD, Kulkarni PS. Polymorphonuclear leukocyte response. Inhibition following corneal epithelial denudation by steroidal and nonsteroidal anti-inflammatory agents. Arch Ophthalmol 1981; 99: 1085-9.

82 Leibowitz HM, Ryan WJ, Kupferman A, De Santis L. Effect of concurrent topical corticosteroid and NSAID therapy of experimental keratitis. Invest topical corticosteroid and NSAID the
Ophthalmol Vis Sci 1986; 27: 1226-9.

83 Arshinoff S, D'Addario D, Sadler C, Bilotta R, Johnson TM. Use of topical nonsteroidal anti-inflammatory drugs in excimer laser photorefractive keratectomy. f Cataract Refract Surg 1994; 20 (suppl): 216-22.

84 Napoli SA, Helm C, Insler MS, Ensley HE, Pretus HA, Feigen LP. External ocular inflammatory effects of lipoxygenase enzyme products. Ann Ophthalmol 1990; 22: 30-4.

85 Palmer RM, Stepney RJ, Higgs GA, Eakins KE. Chemokinetic activity of arachidonic acid lipogenase products on leukocytes of different species. Prostaglandins 1980; 20: 411-7.

86 Stjernschantz J. Autocoids and neuropeptides. In: Sears ML, ed. Pharmacology of the eye. New York: Springer-Verlag, 1984: 311.

87 Johnson D, Aston J. Issues and answers in excimer laser PRK Rev Ophthalmol 1994; 7: 84-93.

88 Ferrari $M$. Use of topical non-steroidal anti-inflammatory drugs after photorefractive keratectomy. F Refract Corneal Surg 1994; 10 (2 suppl): S287-9.

89 Nassaralla BA, Szerenyi K, Wang XW, Al Reaves T, McDonnall PJ. Effect of diclofenac on corneal haze after photorefractive keratectomy in rabbits. Ophthalmology 1995; 102: 469-74.

90 Frew A. Selected side effects: non-steroidal anti-inflammatory drugs and asthma. Prescribers' F 1994; 34: 2.

91 Voltarol ophtha. ABPI data sheet compendium 1995-6: 416-7.

92 Ocufen. ABPI data sheet compendium 1995-6: 74

93 Serle JB. Pharmacological advances in the treatment of glaucoma. Drugs Aging 1994; 5: 157-70.

94 Bito LZ, Stjernschantz J, Resul B, Miranda OC, Basu S. The ocular effects of prostaglandins and the therapeutic potential of a new PGF2 alpha analogue, PhXA41 (latanoprost), for glaucoma management. $\mathcal{f}$ Lipid Mediators 1993; 6: 535-43.

95 Gum CG, Kingsbury S, Whitley RD, Garcia A, Gelatt KN. Effect of topical prostaglandin PGA2. PGA2 isopropyl ester, and PGF2 alpha isopropyl ester on intraocular pressure in normotensive and glaucomatous canine eyes. F Ocular Pharmacol 1991; 7: 107-16.

96 Ando Y, Matsunami C, Yamamoto T, Kitazawa Y. Safety and ocular hypotensive effect of new prostaglandin analogue, S-1033, in normal hypotensive effect of new prostaglandin analogue, S-
volunteers. Acta Soc Ophthalmol fap 1994; 98: 1109-14.

97 Sugrue MF, O'Neill-Davis L. The effect of cyclooxygenase inhibition on the ocular hypotensive action of topical carbonic anhydrase inhibitors in rabbits. F Ocular Pharmacol 1991; 7: 201-11.

98 Trusopt Ophthalmic Solution 2\% (dorzolamide hydrochloride). Merck Sharpe \& Dohme Ltd, Data sheet 1995. 